\title{
Structural and ultrastructural characterization of the embry- onic development of Pseudoplatystoma spp. hybrids
}

\author{
FRANCINE FAUSTINO*,1, LAURA S.O. NAKAGHI ${ }^{1,2}$, CAMILA MARQUES ${ }^{1}$, LUCIANA N. GANECO ${ }^{2}$ \\ and LILIAN C. MAKINO ${ }^{1}$ \\ ${ }^{1}$ Aquaculture Center of São Paulo State University (CAUNESP) and \\ ${ }^{2}$ Department of Morphology and Animal Physiology. Laboratory of Histology and Embryology, \\ Faculty of Agricultural and Veterinary Sciences, São Paulo State University (UNESP), São Paulo, Brazil
}

\begin{abstract}
The hybrid fish Pseudoplatystoma spp. has been raised on a large scale by several fish farmers, despite the fact that little is known about its biology. This is because it presents a number of zootechnical advantages over the parental species. In order to provide information about the early morphology of this important species, we analyzed the fertilization and embryonic development of the hybrid between spotted females and barred males of sorubim specimens by light microscopy and by scanning (SEM) and transmission electron microscopy (TEM) after induced spawning. Samples were collected at pre-established moments up to larval hatching. Seven distinct stages of hybrid embryonic development were identified: zygote, cleavage, morula, blastula, gastrula, histogenesis and organogenesis, and hatching. Under SEM, we observed spermatozoa at the micropyle entrance, the formation of a fertilization cone in the eggs, the differentiation of cephalic and caudal regions, the neural tube and embryo growth along the cephalo-caudal axis, as well as rudimentary optic vesicle and barbels. Under light microscopy, cytoplasmic movement was apparent with the consequent formation of animal and vegetative poles in eggs, in addition to epiboly movements and a small notochord portion. Under TEM, the oocyte chorion and eggs presented a sieve-like aspect in transversal cuts, coupled with the rupture of cortical alveoli and chorion elevation, thus enlarging the perivitelline space. Several mitochondria in the cortical cytoplasm were detected in both oocytes and eggs. Overall, we observed that the larvae hatched without visible morphological alterations, and seemed to be as viable in captive systems as they are in the natural environment.
\end{abstract}

KEY WORDS: P. corruscans, P. fasciatum, hybrid, light and electron microscopy

\section{Introduction}

The genus Pseudoplatystoma comprises the largest fish species of the family Pimelodidae, found in the major South American hydrographic basins. It is composed of the species: Pseudoplatystoma corruscans (spotted sorubim), Pseudoplatystoma fasciatum (barred sorubim) and Pseudoplatystoma tigrinus (tiger sorubim), which are commonly referred to as sorubim catfish. The species $P$. corruscans and $P$. tigrinusoccur in the Amazon Basin; $P$. fasciatumand $P$. corruscans reach the Prata Basin and only $P$. corruscans can be found in the São Francisco Basin (Petrere, 1995).

Both spotted and barred sorubim ( $P$. corruscans and $P$. fasciatum) are considered to be high-quality products, which occupy a large portion of the Brazilian fish market due to their meaty features, such as attractive coloration, firm texture, subtle taste, low fat content and absence of intramuscular spines; they are thus adequate for a wide range of recipes and proposes. Due to these qualities, sorubim species have been targets of predatory overfishing, leading to a gradual reduction of natural stocks, despite the fact that the rationalization of their exploitation has been insisted upon for decades. Furthermore, $P$. corruscans has

Abbreviations used in this paper: SEM, scanning electron microscopy; TEM, transmission electron microscopy.

\footnotetext{
*Address correspondence to: Francine Faustino. Department of Morphology and Animal Physiology. Laboratory of Histology and Embryology, Faculty of Agricultural and Veterinary Sciences, FCAV/UNESP, Via de Acesso Prof. Paulo Donato Castellane s/n, 14.884-900, Jaboticabal, SP, Brazil.

Fax: +55-16-3209-2654 (r. 232)- e-mail: fran_theska@yahoo.com.br
} 
a large potential for sport fishing and as an ornamental fish in the case of younger fishermen (Cury, 1992).

Previous studies concerning the reproductive biology of these species showed that they present full spawning for short periods (two months), high fecundity and no parental care (Leonardo et al. 2004). As for their external morphology, the barred sorubim presents a grayish coloration and several dark vertical bars, sometimes surrounded by small stripes in the dorsal region and dark spots on fins. On the other hand, the spotted sorubim presents several large and dark spots over the body (Castro, 1986).

Although the techniques of induced spawning and incubation have been established for different fish species (Shardo, 1995), reports about the basic aspects of the embryonic development of their inter-specific and intra-generic hybrids are scarce. According to Calcagnotto (1999), hybridization in fish has been studied since the end of the $19^{\text {th }}$ century, and, unlike other vertebrates, the occurrence of both natural and artificial fish hybrids seems to be a common phenomenon. This fact is related to a set of favorable mechanisms affecting reproductive isolation, such as unequal abundance of parental species, competition for limited spawning sites, as well as failures in ethological barriers (Campton, 1988). Hybridization in aquaculture systems is performed in order to improve production rate and to increase the acceptance of the final product by consumers. Successful fish rearing basically depends on knowledge about the biological features of the target species, particularly those associated with reproduction (Leonardo etal.2004). Furthermore, the profitability of a fish culture is closely related to both the rearing abilities of captive species and the
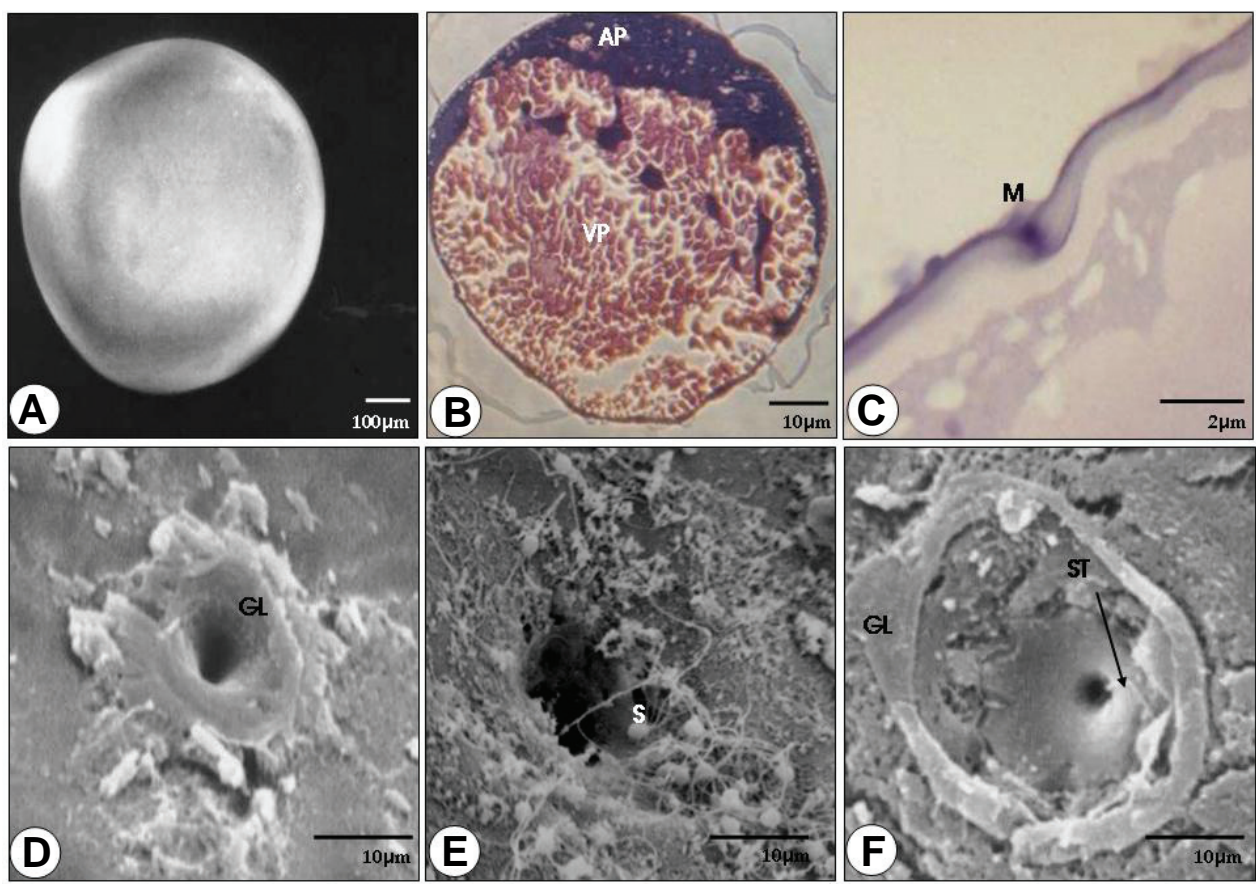

Fig. 1. Oocytes of $\boldsymbol{P}$. corruscans and of $\boldsymbol{P}$. corruscans $\times$ P. fasciatum hybrids. (A) Oocyte viewed by SEM. (B) Oocytes illustrating the animal pole (AP) and the vegetative pole (VP). Light microscopy, embedding paraplast, HE staining. (C) Oocyte showing details of micropyle (M), light microscopy, embedding historesin, HE staining. (D) Oocyte under SEM, revealing details of the micropyle with gelatinous layer (GL). (E) Egg with spermatozoa (S) at micropyle (SEM). (F) Egg with the spermatozoon tail (ST) within the micropyle and gelatinous layer (GL) - SEM. genetic improvement and regular distribution of high-quality larvae to fish farmers. To accomplish these goals, it is essential to understand the basic traits of a fish species to support further studies involving, for instance, selection and genetic improvement of stocks. In fish, the identification of eggs and larvae, coupled with the characterization of morphological and physiological aspects and their developmental alterations contributes to the knowledge of both fishery biology and fish rearing (Nakatani et al. 2001).

In order to provide a detailed characterization of the hybrid forms (spotted $x$ barred sorubim) over early development, we carried out structural and ultrastructural analyses of oocytes of $P$. corruscansand hybrid eggs obtained by induced cross-spawning between spotted sorubim females ( $P$. corruscans) and barred sorubim males ( $P$. fasciatum).

\section{Results}

The embryonic development of the $P$. corruscansx $P$. fasciatum hybrid comprised seven distinct stages (zygote, cleavage, morula, blastula, gastrula, histogenesis and organogenesis, and hatching), each one of them characterized by specific features.

The oocytes of $P$. corruscansfemales (Fig. 1A) presented predefined vegetative and animal poles (Fig. 1B) at the moment of extrusion. The micropylar apparatus of these oocytes was composed of a vestibule and a narrow micropylar canal (Fig. 1 C,D); the former was characterized by a conical shape and smooth surface, without any special arrangements. The micropyle was surrounded by a thick and gelatinous margin (Fig. 1D). Thirty seconds after mixing the oocytes with $P$. fasciatumsperm, several spermatozoa were observed at the micropyle region (Fig. 1E), as well as the tail of a single spermatozoon within the micropyle canal (Fig. 1F), probably representing the moment of fertilization and further zygote formation.

A great yolk mass in the center portion of oocytes was observed, while many cortical alveoli were distributed along the margin of the cortical cytoplasm (Fig. 2A), forming vesicles of distinct sizes (Fig. 2B). The cortical cytoplasm was rich in mitochondria, and contained ribosomes and some secretory vesicles (Fig. 2C). A narrow perivitelline space could be observed at the moment of oocyte extrusion i.e., the chorion had not totally separated from the oocyte plasma membrane (Fig. 2B). Nonetheless, some oocytes already presented a few ruptured cortical alveoli at this moment (Fig. 2D). As development proceeded (10 minutes post-fertilization), the perivitelline space became much wider (Fig. 2E) and cortical alveoli split, suggesting that rupture of alveoli was directly related to the increasing perivitelline space. Un- 


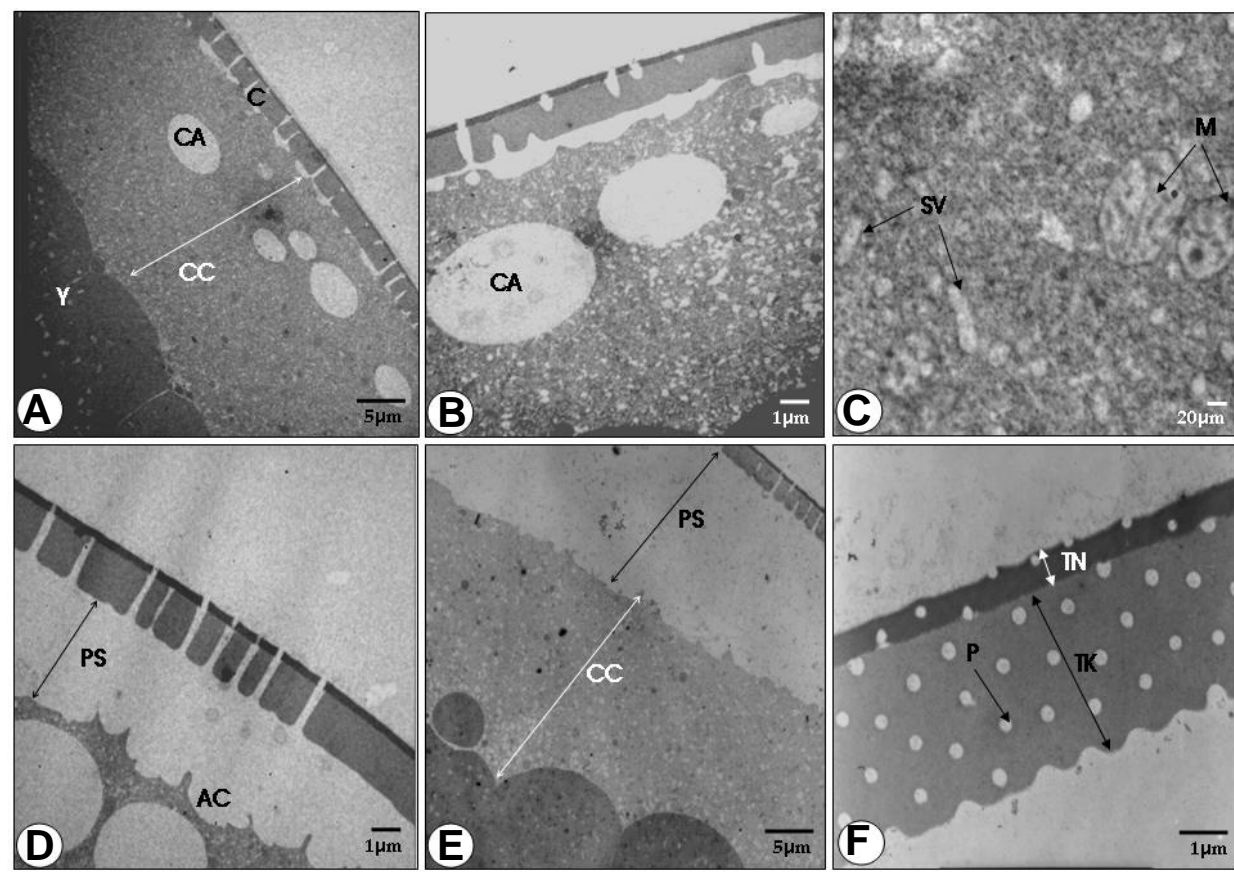

Fig. 2. Oocytes of $P$. corruscans and $P$. corruscans $x$. fasciatum hybrid eggs seen by transmission electron microscopy. (A) Oocyte of $P$. corruscans showing chorion (C), large yolk mass (Y), cortical cytoplasm (CC) with cortical alveoli (CA) at the periphery. (B) Oocyte de P. corruscans showing cortical alveoli (CA) of distinct sizes. (C) Hybrid egg showing secretory vesicles (SV) and mitochondria (M) in the region of cortical cytoplasm. (D) Oocyte of P. corruscans showing the rupture of cortical alveoli (CA) and formation of perivitelline space (PS). (E) Hybrid egg showing cortical cytoplasm (CC) free of cortical alveoli and wide perivitelline space (PS). (F) Hybrid egg showing chorion with pores (P) and composed of a thick (TK) and a thin layer (TN).
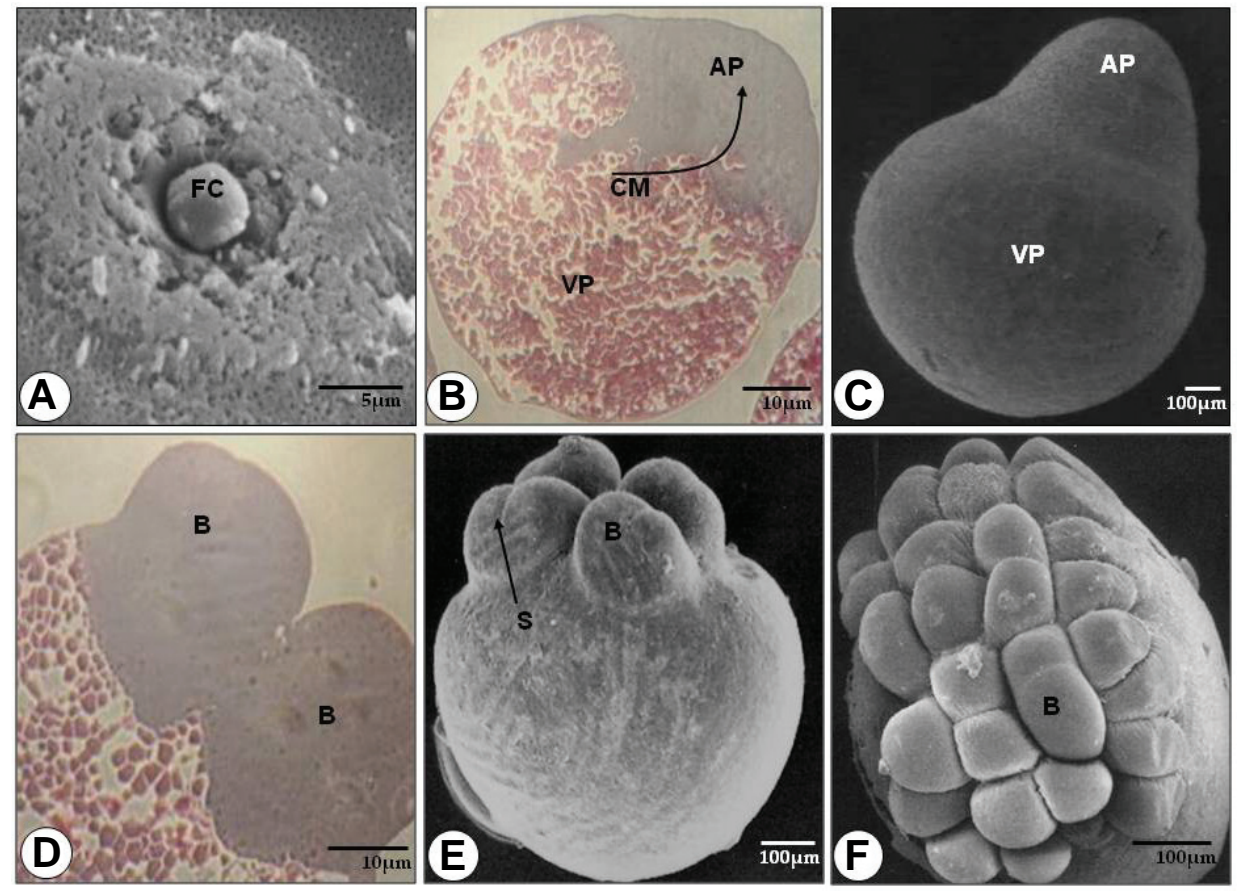

Fig. 3. Hybrid eggs between $\boldsymbol{P}$. corruscans and $\boldsymbol{P}$. fasciatum. (A) Fertilization cone (FC) as seen by SEM. (B) Cytoplasmic movement (CM) and definition of animal pole (AP) and vegetative pole (VP); light microscopy, embedding paraplast, HE staining. (C) Animal pole (blastodisc) (AP) and vegetative pole (VP); SEM. (D) Blastodisc with 2 blastomeres (B); light microscopy, embedding paraplast, HE staining. (E) Blastodisc with 4 blastomeres (B) and division segments (S); SEM. (F) 32 blastomeres (B); SEM. der transversal cuts, the chorion presented a sieve-like shape, due to the presence of several pores, and comprised two layers - a thick and a narrow one (Fig. 2F).

By 1 minute post-fertilization ( $\mathrm{mpf}$ ), the fertilization cone had been formed, represented by a spherical structure emerging from the micropyle, blocking the entry and the passage of other spermatozoa, thereby avoiding polyspermy (Fig. 3A). Between 20 and $40 \mathrm{mpf}$, egg cytoplasm began to move (Fig. 3B), leading to the formation of the animal and vegetative poles (blastodisc formation) (Fig. 3C). The cleavage stage initiated right after definition of the blastodisc: the first cleavage divided the blastodisc into two blastomeres (cells) of similar size (Fig. 3D) which subsequently divided to form four blastomeres (Fig. 3E). Two and four blastomeres could be observed between 30 and $45 \mathrm{mpf}$, respectively. Cleavages followed successively, giving rise to eight, 16 and 32 cells (Fig. 3F), between 60 and 75 mpf.

The morula stage, during which the blastomeres formed a cell mass resembling a "half-berry", was visualized between $90 \mathrm{mpf}$ (the initial morula stage, Fig. 4A) and $120 \mathrm{mpf}$ (the final morula, Fig. 4B). The subsequent blastula stage is characterized by the formation of irregular spaces between the embryonic cells and the presence of the yolk syncitial layer, both features being most clearly observed using light microscopy. Unfortunately, we were unable to record data from this stage, but we estimate that the blastula stage could have occurred probably between 2 and 3 hours post fertilization (hpf).

The subsequent gastrula stage was characterized by epiboly movements in which cells started moving from the animal pole towards the vegetative pole. Epiboly began within 3 to $4 \mathrm{hpf}$ (Fig. 4C). Between 4 and 5 hpf, $50 \%$ epiboly was observed (Fig. 4D), reaching 75\% epiboly between 5 and 6 hpf (Fig. 4E). By 7 hpf, the movement had ended, culminating with the closure of the blastopore by the blastoderm and the formation of the yolk plug, i.e., a portion of the yolk that remained uncovered by the blastoderm when the cell movements stopped (Fig. 4F).

At the beginning of the histogenesis and organogenesis stage (after $8 \mathrm{hpf}$ ), the development of cephalic and caudal 


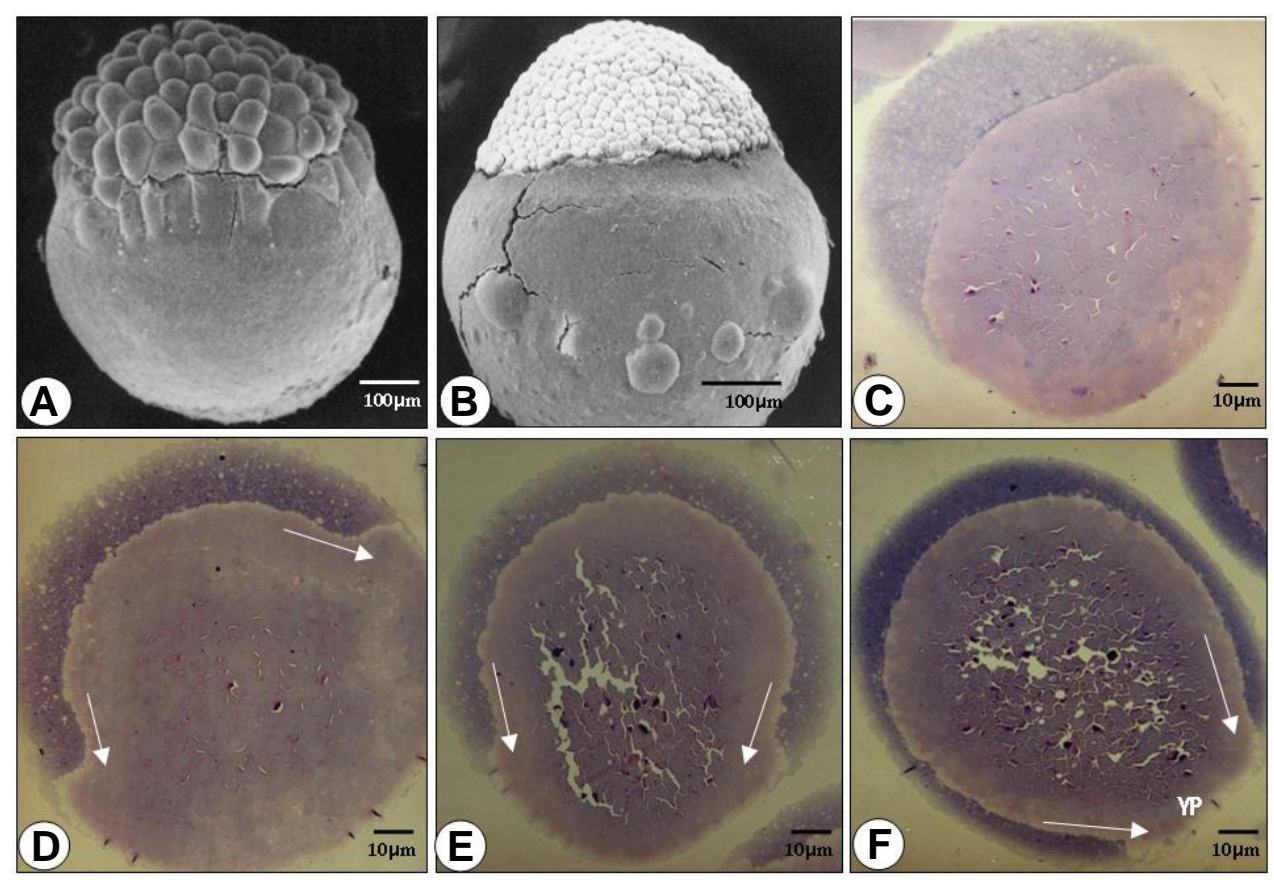

Fig. 4. Hybrid eggs between $\boldsymbol{P}$. corruscans and $\boldsymbol{P}$. fasciatum. (A) Morula initial stage as seen by SEM. (B) Morula final stage; SEM. (C) Beginning of the gastrula stage (epiboly movement); light microscopy, embedding historesin, HE staining. (D) Gastrula with $50 \%$ of the egg covered by epiboly movement (arrow); light microscopy, embedding historesin, HE staining. (E) Gastrula with $75 \%$ of the egg covered by epiboly movement (arrow); light microscopy, embedding historesin, HE staining. (F) End of the epiboly movement (arrow) with the formation of the yolk plug (YP); light microscopy, embedding historesin, HE staining.

regions was noticeable (Fig. $5 \mathrm{~A}$ ), as well as the presence of somites (Fig. 5B) within 8 and $9 \mathrm{hpf}$ and the growth and elongation of the embryo through the cephalo-caudal axis between 9 and 10 hpf (Fig. 5C). After 11 to $12 \mathrm{hpf}$, the neural tube enlarged giving rise to the prosencephalon (Fig. 5D), mesencephalon and rhombencephalon regions. The formation of the optic vesicle, close to the prosencephalon and rudimentary barbels could also be detected at this moment (Fig. 5E). The observation of a free tail and the consequent chorion rupture (larval hatching) took place within 13 and $14 \mathrm{hpf}$, when the head was directed downwards, attached to the anterior region of the yolk and the body was extended, with a large yolk and absence of fins (Fig. 5 F,G).

\section{Discussion}

The characterization of the embryonic development of the hybrid between Pseudoplatystoma corruscans and Pseudoplatystoma fasciatum is essential to provide improved knowledge about the biology, morphology and physiology of this fish which has been intensively raised by private producers and is in high demand in the fish culture market. Besides increasing our knowledge of biological aspects of this fish, the characterization of the embryonic stages in teleosteans is of use for both aquaculture and fisheries (Matkovic et al. 1985), since it provides useful information for mass controlled fish production in laboratories, as well as for systematics and environmental inventories (Ninhaus-Silveira, et al. 2006).

The rearing of $P$. corruscans and $P$. fasciatum in captivity is important in order to provide for adequate human consumption, to reduce fishing pressure and also to facilitate repopulation of overexploited species. The hybrids Pseudoplastystoma spp. have been raised in many fish culture facilities instead of the pure species. According to fish farmers, this happens because they present a number advantages with respect to the parental species in terms of management; the hybrids can be handled more easily, accept well prepared foods and grow faster (Crepaldi et al. 2003). On the other hand, it should be pointed out that their escape from aquaculture facilities represents a potential risk to river systems, and could have a drastic environmental impact, threatening the genetic pool of the original species. Thus, the aim of the present study was to contribute to our knowledge of the early biology of this important hybrid fish species, with a particular focus on fertilization and embryonic development, since these features may have implications for fertilization rate and larval hatching.

The stages observed during the embryonic development of the hybrid (zygote, cleavage, morula, blastula, gastrula, histogenesis and organogenesis, and hatching) were also reported by Nakaghi et al. (2006) in Salminus brasiliensis, by Ninhaus-Silveira et al. (2006) in Prochilodus lineatus and by Marques et al. (2008) in Pseudoplastystoma corruscans. The region in which the spermatozoon penetrates the oocyte at the moment of fertilization is called the micropyle (Riehl, 1993). According to Rizzo etal. (2002) and Ganeco and Nakaghi (2003), the micropyle is a concave region located at the zona radiata (chorion), and consists of an internal vestibule which is continuous with an internal canal that narrows towards the plasma membrane of the egg. Its morphology is variable among distinct teleostean species (Riehl and Kokoscha, 1993). Although the functional significance of ultrastructural differences on the oocyte surface has not been completely elucidated, it is thought that such variation might play a key role during the fertilization process, as well as in egg adherence and protection against environmental pathogens. Moreover, the ultra-structural features of the micropyle is important for the identification of eggs and is useful to clarify the phylogenetic relationships within and among different groups of teleosteans (Breining and Britz, 2000). The micropyle vestibule in the hybrid between $P$. corruscans and $P$. fasciatum presented a smooth surface, free of any special arrangement, surrounded by a thick and gelatinous border. Most of the Siluriform fish analyzed by Rizzo et al. (2002) were also characterized by a gelatinous border around the vestibule. According to Kobayashi and Yamamoto (1981) and Hart and Donovan (1983), the diameter of the micropyle canal is equivalent to the size of the spermatozoon head, acting as a mechanical barrier to polyspermy, since just the first 
spermatozoon reaching the micropyle is able to establish direct contact with the plasma membrane of the oocyte. During fertilization, a large number of spermatozoa compete to fertilize a single oocyte, as observed at the micropylar region in the hybrid egg 30 seconds after fertilization. Freire-Brasil (2001) and Ganeco et al. (2008), analyzing fertilization in Prochilodus lineatus and Brycon orbinyanus, reported that several spermatozoa reach and pass through the micropyle, reinforcing the development of distinct strategies in fish to avoid polyspermy. Hart (1990) pointed out some of them, such as: the presence of chorion as well as micropyle, modifications in the site of spermatozoon entrance, obstruction of the micropylar canal and inhibition of spermatozoa by fluids from the perivitelline space.

Regarding the pores found in the chorion of the $P$. corruscans $x$ P. fasciatum hybrid, Guraya (1986) stated that they represent radial and conspicuous striae caused by the presence of porechannels filled with oocyte microvilli and/or follicle cells during maturation. According to Laale (1980) and Iwamatsu (2000), the elevation of the zona radiata, initiated by the cortical reaction, gives rise to the perivitelline space. The first author suggested that the perivitelline space may exert some functions such as the
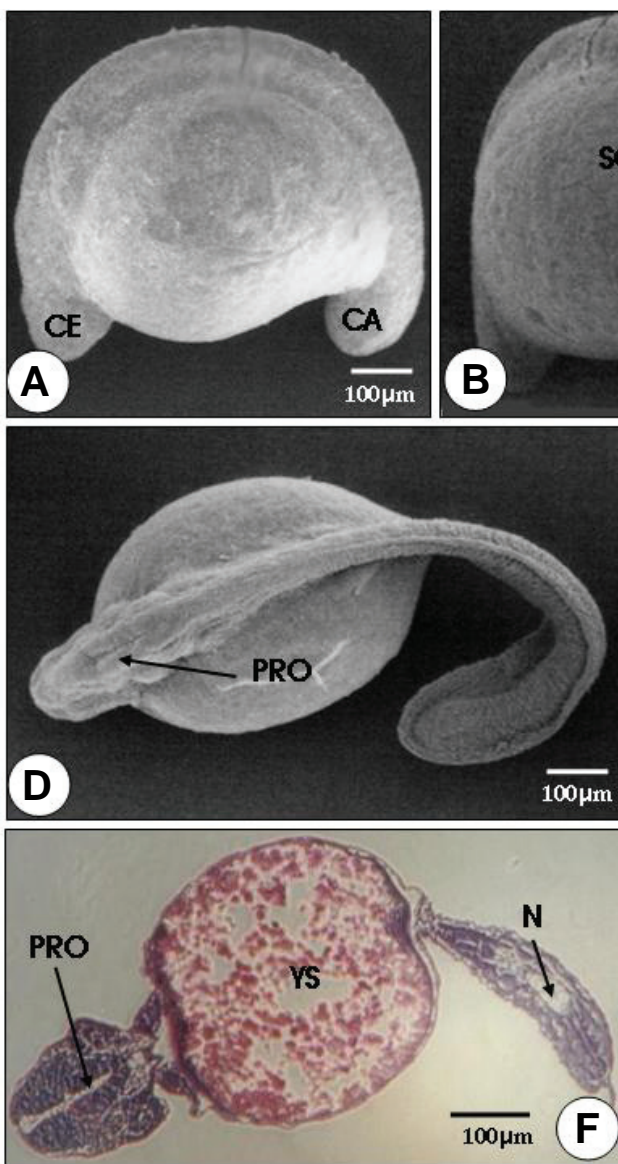

Fig. 5. $\boldsymbol{P}$. corruscans and $\boldsymbol{P}$. fasciatum hybrid larvae. (A) Differentiation of cephalic (CE) and caudal (CA) regions as viewed by scanning electron microscopy. (B) Observation of the first somites (SO); SEM. (C) Elongation of the embryo through cephalo-caudal axis (CC); SEM. (D) Anterior region of the neural tube with detail of the prosencephalon (PRO); SEM. (E) Rudimentary barbels (BA) and optic vesicle (OV) (in detail); SEM. (F) Newly hatched larvae showing a portion of the yolk sac (YS), notochord (N) and prosencephalon (PRO); light microscopy, embedding historesin, HE staining. (G) Newly hatched larvae as seen with SEM. protection, nutrition, osmotic regulation and flotation of the embryo, in addition to preventing polyspermy. Matsumura (1972) suggested that the perivitelline space protects the embryo against environmental injuries and contributes to enhancing survival rate in fast-flowing waters. The perivitelline space observed in the sorubim hybrid was quite large, indicating increased protection to these embryos which are exposed in wildlife to several factors which could jeopardize their development. The enlargement of this space in the same hybrid is quite visible under stereomicroscopy, as shown by Faustino et al. (2007).

Cortical alveoli have been reported to be present in the cortical cytoplasm and to look like vesicles of distinct sizes, limited by a membrane; similar alveoli were observed in the hybrid eggs in the present study. Guraya (1986) suggested that such alveoli contain substances which react positively to periodic acid-Schiff (PAS), and are likely to be produced by the oocyte itself (self-synthetic). Recent studies using lectins of different specificities revealed that the content of cortical alveoli in several species of notothenioid fish is variable (Motta et al. 2005). In addition to species-specific variations in cortical alveoli content, the composition of cortical vesicles may also vary during oocyte development within a single species (Ohta et al. 1990). It is known that during fertilization, cortical alveoli fuse with the plasma membrane, releasing their content into the perivitelline space, thereby creating a barrier to polyspermy in fish (Yamamoto, 1956). Furthermore, Laale (1980) reported that during the exocytosis of cortical alveoli content, $\mathrm{Ca}^{+2}$ ions are absorbed from the external medium to take part in chorion hardening, thus contributing to the mechanical protection of the developing embryo. In a study performed by Freire-Brasil (2001) in P. lineatus, it was shown that the content of the cortical alveoli was deposited between the chorion and the oocyte membrane in the recently formed perivitelline space, even before spermatozoon penetration. The author claimed that this is reasonable, as long as the entrance of either the fertilizing spermatozoon or supernumerary ones takes place rapidly and the oocyte would require a minimum initial condition to prevent polyspermy. The same feature could be observed in our hybrids, since the rupture of some cortical alveoli (cortical reaction) and the formation of a small perivitelline space were detected at the moment of extrusion and prior the fertilization.

According to Ohta et al. (1990), oocytes become activated by a fertilizing spermatozoon or by the addition of freshwater. Some reports indicate, either explicitly or implicitly, that the cortical reaction should be the first detectable response in the oocyte to spermato- 
zoon fusion (Selman and Wallace, 1989). However, other studies carried out by Kudo (1978) and Renard et al. (1990), showed that the oocyte reaction in freshwater fish begins when the oocyte is in contact with water, independently of the fertilization process. Based on these issues, it should be pointed out that the cortical reaction observed at extrusion in the present work could be due to some accidental contact between gametes and water, thus stimulating the early rupture of such vesicles, inasmuch as activation through hydration occurred only 40 seconds after fertilization. Moreover, the observation of spermatozoa around the micropyle at 30 seconds post-fertilization is another indication of accidental contact of the gametes with water.

According to Laale (1980) and Hart (1990), the causative relationship between the rupture of cortical alveoli and the elevation of the chorion was first reported by Yamamoto in 1944. Such elevation was primarily derived from water absorption, apart from the fertilization process in most analyzed species. Actually, the zona radiata is permeable to water, small electrolytes, sugar and staining substances, but not to the exudate of cortical alveoli (Hart, 1990). Therefore, an osmotic gradient is established and penetration of water and solutes takes place.

The fertilization cone acts as another mechanism to prevent polyspermy, hindering the entrance of extra spermatozoa (Ganeco and Nakaghi, 2003). This structure was observed in the eggs analyzed in the present study, blocking the passage of spermatozoa to the inner micropyle portion. Iwamatsu (2000) reported that the cone is composed of perivitelline fluid released through the micropyle canal, forming a bubble. The beginning of the formation of the fertilization cone occurs at the same time as the exocytosis of the cortical alveoli (Iwamatsu and Ohta, 1981). Yamamoto (1964) showed that the cortical layer in the cytoplasm of mature oocytes of Oryzias latipes present large lipid vesicles, several mitochondria and small endoplasmic reticule vesicles. All of these components were identified in eggs of the $P$. corruscans $\times P$. fasciatum hybrid, mainly mitochondria, thereby indicating a high mitotic index.

Brummett and Dumont (1981) observed that right after the rupture of cortical alveoli, a protoplasmic cover accumulates in the animal pole, forming the blastodisc, where segmentation takes place. In fact, after the cortical reaction in the eggs which we analyzed, a cytoplasmic movement was observed, leading to the differentiation of both vegetative and animal poles and the beginning of cleavage. The type of cleavage which we observed in the hybrid is typical for fish eggs, i.e., meroblastic or partial cleavage, and it was similar to that reported for other teleosteans (Marques et al. 2008). During cleavage, we observed that the number of blastomeres (undifferentiated embryonic cells) increased while their size decreased during development, a feature also reported by other authors (Wourms and Evans, 1974; Ninhaus-Silveira et al. 2006). During the morula stage, more than 64 embryonic cells arranged in two or more layers can be observed forming a domeshaped blastoderm (Marques et al. 2008). During the blastula stage, the embryonic cells of the blastoderm are still undifferentiated, and cell divisions occur at a slower rate (Kane and Kimmel, 1993). During this stage, the yolk syncitial layer and the irregular spaces between the cells of the blastoderm are formed, as observed in some teleosteans (Kimmel and Law, 1985; Kimmel et al. 1995). The yolk syncitial layer is an extraembryonic layer and does not participate in embryo formation; rather it is important in the breaking of the yolk, making it available for consumption by the embryo (Balinsky, 1970). Regarding the irregular spaces that arise between blastoderm cells, Kimmel et al. (1995) have suggested that this stage could be better defined as the stereoblastula, since the formation of the blastocoel cavity has not yet formed. However, other authors have not differentiated between these stages in teleosteans and merely report the presence of the blastocoel (Lagler et al. 1977). Nevertheless, both cavities between the embryonic cells as the yolk syncitial layer are difficult to view, and are best observed using a light microscope. In this study, we were unable to record this phase using the employed methodology.

The gastrula is the stage characterized by epiboly movements, differentiation and cell migration. In epiboly, blastoderm cells move to cover the yolk mass, and during migration, the internal blastoderm cells move dorsally and convergently to form the embryo axis (Leme dos Santos and Azoubel, 1996). The epiboly steps were followed in the present study, being characterized by the movement of cells from the animal pole towards the vegetative pole. After the gastrula stage and the consequent formation of embryonic follicles, rudimentary organs and primitive tissues of the developing animal usually begin to be formed (Leme dos Santos and Azoubel, 1996). This stage is known as the histogenesis and organogenesis stage. In the analyzed hybrid, the anterior region of the neural tube expanded to form the prosencephalon, mesencephalon and rhombencephalon regions, similar to the pattern reported in Brachidanio rerio by Kimmel et al. (1995) and in Rhamdia sapoby Cussac et al. (1985). The formation of primordial barbels in the sorubim hybrid was also identified by Cestarolli (2005) in $P$. corruscans.

Embryogenesis of the hybrid in the present study, from fertilization to larval hatching, was short, lasting 13 to 14 hours. According to Vandewalle et al.(2005) fast embryonic development is typical of migratory species with seasonable reproductive strategies, high fecundity and no parental care, like those used to produce the hybrid in the present study, i.e. $P$. corruscans and $P$. fasciatum. Blaxter (1969) showed that the majority of recently-hatched fish larvae lack a mouth, intestine, anus, gills, swim bladder, even fins, pigmentation and visual accuracy. These structures were also absent in the hybrid larvae which, consequently, are incapable of facing adverse environmental conditions, such as searching for food and escaping from predators. In reophilic species, the adaptation period to adverse environmental conditions is short, so the larvae can reach the juvenile stage as fast as possible, developing the minimum requirements to survive under such harsh environmental conditions (Vandewalle et al. 2005).

Based on these results, it can be concluded that newly-hatched larvae do not exhibit morphological alterations which could hinder their viability either in captivity or in their natural habitat. Thus, we strongly recommend that the production of hybrids, in spite of their zootechnical advantages, should be carefully monitored to prevent accidental escapes into the natural habitats since this could lead to profound changes or even extinction of the pure parental species.

\section{Material and Methods}

Three samplings were carried out in December 2004 at the Centro de Pesquisa e Gestão de Recursos Pesqueiros Continentais (CEPTA/IBAMA), Pirassununga-SP, after induced spawning in females of the spotted sorubim ( $P$. corruscans) and males of the barred sorubim ( $P$. fasciatum), following 
the methodology described by Faustino et al. (2007). After extrusion, the oocytes were kept in a bowl and sperm was added and gently homogenized. Egg hydration was performed for gamete activation 40 seconds after fertilization. The eggs were transferred into $60 \mathrm{~L}$ conic incubators at an estimated concentration of 1,000 eggs/L (60,000 eggs per incubator). Water flow during the initial development stages was equal to $5 \mathrm{~L} / \mathrm{min}$ and from the final incubation up to hatching it was increased up to $10 \mathrm{~L} / \mathrm{min}$, with water temperature between 27 and $29^{\circ} \mathrm{C}$. The samples were collected at the following stages: moment of oocyte extrusion, moment of oocyte and sperm mixing (time zero), at 10 and 30 seconds, 1, 2, 5, 8, 10, 15, 20, 30, 45 minutes and 1 hour after mixing, and every hour up to larval hatching.

The samples were fixed in Karnovsky's solution (2.5\% glutaraldehyde $+2.5 \%$ paraformaldehyde) for 24 hours and washed in $0.1 \mathrm{M}$ cacodylate buffer, $\mathrm{pH}$ 7.4. A part of the material was stored in $70 \%$ alcohol for light microscopy analysis. Sample processing was performed in the Histology Laboratory at the Morphology and Animal Physiology Department and in the Electronic Microscopy Laboratory, both at FCAV-UNESP, Jaboticabal $-\mathrm{SP}$, Brazil.

\section{Light microscopy}

Samples were divided for paraplast and historesin embedding. The samples selected for paraplast embedding were kept for 5 minutes in each of a series of solutions for dehydration $(80 \%, 90 \%$ and $95 \%$ ethanol, absolute alcohol I, II and III) and clearing (xylol I, II and III), respectively. Then, the samples were kept for 20 minutes in each paraplast embedding stage, following the material inclusion. Depending on the nature of the biological material, the microtomy technique was adapted to obtain the best observation quality. Therefore, the blocks were trimmed and the cut side was immersed into a solution containing glycerin and distilled water (1:1) for 24 hours. Histological sections of $4 \mathrm{~mm}$ thickness were obtained.

For historesin embedding (Historesin Plus, Leica, Heidelberg, Germany), the samples were dehydrated for 24 hours in $80 \%$ ethanol and then washed twice in $90 \%$ and $100 \%$ alcohol for 30 minutes each. Afterwards, the samples were stored for 4 hours in a pre-embedding solution consisting of GMA (Glycol Methacrylate) + ethanol (1:1) and 16 hours in the embedding stage (GMA), for further inclusion in histomold. The samples were placed in a drier at $60^{\circ} \mathrm{C}$ for 24 hours and cut at a thickness of $2 \mu \mathrm{m}$. All cuts (both paraffin and historesin embedding) were stained with Hematoxylin-Eosin (HE). Analysis and photodocumentation were carried out using an AXIOSKOP-ZEISS photomicroscope coupled with LEICA DFC 280 equipment.

\section{Electron microscopy}

The samples were post-fixed in $1 \%$ osmium tetroxide for 2 hours and washed again in cacodylate buffer. Then, they were dehydrated in a graded series of ethanol at $30,50,70,80,90$ and $95 \%$ concentrations plus three baths at $100 \%$ (7 minutes each).

\section{Scanning Electron Microscopy (SEM)}

The samples were dried to the critical point in a liquid $\mathrm{CO}_{2}$ drier (BALTEC), mounted on a copper grid, metallized with gold-palladium ions in a Desk II Denton Vacuum equipment and observed under a scanning electron microscope (JEOL-JSM 5410).

\section{Transmission Electron Microscopy (TEM)}

The early stages of hybrid embryo development were analyzed. Stages which were sampled included extrusion, fertilization, 10 seconds, 30 seconds, $1 \mathrm{mpf}$ and $10 \mathrm{mpf}$. The samples were pre-embedded in a mixture of resin and ethanol (1:1) for 18 hours. The material was embedded in resin and then, semi-fine cuts $(300 \mathrm{~nm})$ were obtained, mounted onto slides and stained with $1 \%$ toluidine blue in saturated boric acid for analysis and selection of areas to be observed under transmission electron microscope. Ultra-fine cuts of $70 \mathrm{~nm}$ thickness were obtained using an ultramicrotome model ULTRACUT-LEICA, with a diamond knife, and mounted on a copper grid covered with pioloform (polyvinyl butyral).
The samples were counterstained with uranyl acetate and lead citrate, observed using a transmission electron microscope (JEOL-JEM 1010) and electronmicrographed using plates.

\section{Acknowledgements}

The authors would like to thank CEPTA-IBAMA for providing the biologic material and the facilities, and FAPESP for the financial support (Processes 04/06010-9, 06/51326-0).

\section{References}

BALINSKY, B.I. ( 1970). An introduction to embryology. W. B. Saunders, Philadelphia, pp. 353

BLAXTER, J.H.S. (1969). Development: eggs and larvae. In Fish Physiology (Eds. W.S. Hoar and D.J. Randall). Vol. 3. Academic Press, New York, pp. 178-252.

BREINING, T. and BRITZ, R. (2000). Egg surface structure of clingfish species, using scanning electron microscopy. J Fish Bio/56: 1129-1137.

BRUMMETT, A.R. and DUMONT, J. (1981). Cortical vesicle breakdown penetration into the eggs of Fundulus heteroclitus. J Exp Zoo/216: 63-79.

CALCAGNOTTO, D., TOLEDO, L.F.A., BERNARDINO, G. and TOLEDO-FILHO, S.A. (1999). Biochemical genetic characterization of $F 1$ reciprocal hybrids between neotropical pacu ( Piaractus mesopotamicus) and tambaqui (Colossoma macropomum) reared in Brazil. Aquaculture 174: 51-57.

CAMPTON, D.E. (1988). Natural hybridisation and introgression in fishes. Methods of detection and genetic interpretations. In Population genetics and fishery management (Eds. N. Ryman and F. Utter). University of Washington Press, London, pp. 161-192.

CASTRO, D. (1986). Los bagres de la subfamilia Sorubiminae de la Orinoquia y Amazonas Colombiana (Siluriformes: Pimelodidae). Bol Ecotrop 13: 1-14.

CESTAROLLI, M.A. (2005). Larvicultura do pintado Pseudoplatystoma coruscans (Agassiz, 1829): aspectos da alimentação inicial e do desenvolvimento de estruturas sensoriais. 2005. Tese de Doutorado, Centro de Aqüicultura da Universidade Estadual Paulista, Jaboticabal.

CREPALDI, D.V., TEIXEIRA, E.A., RIBEIRO, L.P., MIRANDA, M.O.T., SOUZA, A.B. and MELO, D.C. (2003). Growth of Hybrid surubim $P$. coruscans X $P$ fasciatum at different stock density. World Aquaculture 2003. World Aquaculture Society, pp. 784. (Abstr.).

CURY, M.X. (1992). Cultivo de pintado e cachara. Panorama da Aqüicultura, Rio de Janeiro, pp. 8-9.

CUSSAC, V.E., MATKOVIC, M.V. and MAGGESE, M.C. (1985). Desarrollo embrionário de Rhamdia sapo (VALENCIENNES, 1840) EIGENMANN Y EIGENMANN, 1888 (PISCES, PIMELODIDAE), I. Organogenesis media, organogenesis tardia y eclosion. Rev Bras Bio/45: 149-160.

FAUSTINO, F., NAKAGHI, L.S.O., MARQUES, C., MAKINO, L.C. and SENHORINI, J.A. (2007). Fertilização e desenvolvimento embrionário: morfometria e análise estereomicroscópica dos ovos dos híbridos de surubins (pintado, Pseudoplatystoma corruscans $\times$ cachara, Pseudoplatystoma fasciatum). Acta Sci 19: 49-55.

FREIRE-BRASIL, D. (2001). Análise estrutural e ultraestrutural da maturação final do ovócito, fertilização e primeira clivagem em curimbatá, Prochilodus lineatus Valenciennes, 1936. Tese de Doutorado, Centro de Aqüicultura da Universidade Estadual Paulista, Jaboticabal.

GANECO, L.N. and NAKAGHI, L.S.O. (2003). Morfologia da micrópila e da superfície de ovócitos de piracanjuba, Brycon orbignyanus (Osteichthyes, Characidae), sob microscopia eletrônica de varredura. Acta Sci25: 227-231.

GANECO, L.N., FRANCESCHINI-VICENTINI, I.B. and NAKAGHI, L.S.O. (2008) Structural analysis of fertilization in the fish Brycon orbignyanus. Zygote 17: 9399.

GURAYA, S.S. (1986). The cell and molecular biology of fish oogenesis. In Monographs in Developmental Biology (Ed. H.W. Sauer). Karger, Vol. 18. Basel, pp. 1-213.

HART, N.H. (1990). Fertilization in teleost fishes: mechanisms of sperm-egg interactions. Int. Rev Cyto/121:1-66.

HART, N.H. and DONOVAN, M. (1983). Fine structure of the chorion and site of sperm entry in the egg of Brachydanio. J Exp Zoo/227: 261-296. 
IWAMATSU, T. and OHTA, T. (1981). Scanning electron microscopic observation on sperm penetration in teleostean fish. J Exp Bio/218: 261-277.

IWAMATSU, T. (2000). Fertilization in fishes. In: Fertilization in Protozoa and Metazoa Animals. (Ed. J.J. Tarín and A. Cano). Springer-Verlag Berlin, Heidelberg, pp. 89-145.

KANE, D.A. and KIMMEL, C. B. (1993). The zebrafish midblastula transition. Development 119: 447-456.

KIMMEL, C.B. and LAW, R.D. (1985). Cell lineage of zebrafish blastomeres. II. Formation of the yolk syncitial layer. Dev Bio/108: 86-93.

KIMMEL, C.B., BALLARD, W.W., KIMMEL, S.R. and ULLMANN, B. (1995). Stages of embryonic development of the zebrafísh. Dev Dyn 203: 253-310.

KOBAYASHI, W. and YAMAMOTO, T. (1981). Fine structure of the micropylar apparatus of the chum salmon egg, with a discussion of the mechanism for blocking polyspermy. J Exp Zoo/217: 265-275.

KUDO, S. (1978). Enzymo-cytochemical observations on the cortical change in the eggs of Cyprinus carpioand Carassius auratus. Dev Growth Differ20: 133-142.

LAALE, W. H. (1980). The perivitelline space and egg envelopes of Bony fishes: a review. Copeia 2: 210-226.

LAGLER, K.F, BARDAK, J.E., MILLER, R. R. and PASSINO, D.R.M. (1977). Ichthyology: The Study of Fishes. John Wiley and Sons Ltd, New York, pp. 489.

LEME DOS SANTOS, H.S. and AZOUBEL, R. (1996). Embriologia comparada. FUNEP, Jaboticabal, pp. 189.

LEONARDO, A.F.G., ROMAGOSA, E., BATLOUNI, S.R. and BORELLA, M.I. (2004). Characterization and hormonal efficiency in female cachara, Pseudoplatystoma fasciatum (Linnaeus, 1766), kept in captivity. Aquaculture 42: 451-461.

MATKOVIC, M., CUSSAC, V.E., CUKIER, M., GUERRERO, G.A., MAGGESE, M.C. Desarrollo embrionario de Rhamdia sapo(Valenciennes, 1840) Eigenmann y Eigenmann, 1888 (Pisces, Pimelodidae). I. Segmentación, morfogénesis y organogénesis temprana. Rev Bras Biol, São Carlos, v. 45, n. 1/2, p. 39-50. 1985.

MATSUMURA, Y. (1972). Egg development of scaled sardine Harengula pensacolae Goode e Bean (Pisces, Clupeidae). Bol Inst Ocean 21: 129-135.

MARQUES, C., NAKAGHI, L.S.O., FAUSTINO, F. GANECO, L.N. and SENHORINI, J.A. (2008). Observation of the embryonic development in Pseudoplatystoma coruscans (Siluriformes: Pimelodidae) under light and scanning electron microscopy. Zygote 16: 333-342.

MESQUITA, F.C.M. (1989). Legislação pesqueira para o Pantanal: lazer e esporte no meio ambiente. Rev Aruanã 17: 66-67.

MOTTA, C.M., TAMMARO, S., SIMONIELLO, P., PRISCO, M., RICCHIARI, L., ANDREUCCETTI, P. and FILOSA, S. (2005). Characterization of cortical alveoli content in several species of Antarctic notothenioids. J Fish Bio/66: 442-453.

NAKAGHI, L.S.O., MARQUES, C., FAUSTINO, F., MAKINO, L.C. and SENHORINI,
J.A. (2006). Desenvolvimento embrionário do dourado (Salminus brasiliensis) por meio de microscopia eletrônica de varredura. Bol Tec Cepta 19: 9-19.

NAKATANI, K., AGOSTINHO, A.A., BAUMGARTNER, G., BIALETZKI, A., SANCHES, P.V., MAKRAKIS, M.C. and PAVANELLI, C.S. (2001). Ovos e larvas de peixes de água doce: Desenvolvimento e manual de identificação. Maringá: Editora da Universidade Estadual de Maringá, pp. 378.

NINHAUS-SILVEIRA, A., FORESTI, F. and AZEVEDO, A. (2006). Structural and ultrastructural analysis of embryonic development of Prochilodus lineatus (Valenciennes, 1836) (Characiforme; Prochilodontidae). Zygote 14: 217-229.

OHTA, T., IWAMATSU, T., TANAKA, M. and YOSHIMOTO, Y. (1990). Cortical alveolus breakdown in the eggs of the freshwater teleost Rhodeus ocellatus ocellatus, Anat Record 227: 486-496

PETRERE Jr., M. (1995). A pesca de água doce no Brasil. Ciência Hoje 19: 28-33.

RENARD, P., FLECHON, B., BILLLARD, R. and CHRISTEN, R. (1990). Biochemical and morphological changes in the chorion of the carp (Cyprinus carpio) oocyte, following the cortical reaction. J App/ /chthyo/6: 81-90.

RIEHL, R. (1993). Surface morphology and micropyle as a tool for identifying fish eggs by scanning electron microscopy. MicrosC Ana/29-31.

RIEHL, R. and KOKOSCHA, M. (1993). A unique surface pattern and micropylar apparatus in the eggs of Luciocephalus sp. (Perciformes, Luciocephalidae), J Fish Bio/43: 617-620.

RIZZO, E., SATO, Y., BARRETO, B.P. and GODINHO, H.P. (2002). Adhesiveness and surface patterns of eggs in neotropical freshwater teleosts. J Fish Bio/61: 615-632.

SELMAN, K. and WALLACE, R.A. (1989). Cellular aspects of oocyte growth in teleosts. Zool. Sci. 6: 211-231.

SHARDO, J.D. (1995). Comparative embryology of teleostean fishes. I. Development and staging of the American Shad, Alosa sapissima (Wilson, 1811). J. Morphol. 225: 125-167.

VANDEWAlle, P., GeRMEAU, G., Besancenet, P., PARMENTIER, E. and BARAS, E. (2005). Early development of the head skeleton in Brycon moorei (Pisces, Ostariophysi, Characidae). J. Fish Biol. 66: 996-1024.

WALLACE, R.A. and SELMAN, K. (1981). Cellular and dynamic aspects of oocyte growth in teleosts. Amer Zoo/21: 325-343.

WOURMS, J.P. and EVANS, D. (1974). The embryonic development of the black pricleback, Xiphister atropurpureus, a Pacific Coast blennioid fish. Can J Zool 52: $879-887$

YAMAMOTO, T. (1956). Studies on the formation of fish eggs. VII. The fate of the yolk vesicle in the oocyte of the smelt, Hypomesus japonicus, during vitellogenesis. Embryologia 3: 131-138.

YAMAMOTO, M. (1964). Electron microscopy of fish development. III. Changes in the ultrastructure of the nucleus and cytoplasm of the oocyte during its development in Oryzias latipes. J Fac Sci Univ Tokyo, 10: 335-346. 


\section{Further Related Reading, published previously in the Int. J. Dev. Biol.}

See Special Issue Pattern Formation edited by Michael K. Richardson and Cheng-Ming Chuong at:

http://www.ijdb.ehu.es/web/contents.php?vol=53\&issue =5-6

A novel in vitro system for studying cardiomyocyte differentiation with medaka embryonic cells

Masao Hyodo, Shinji Makino, Yasunori Awaji, Yohei Sakurada, Tomoichi Ohkubo, Mitsushige Murata, Keiichi Fukuda and Michio Tsuda

Int. J. Dev. Biol. (2009) 53: 615-622 (doi: 10.1387/ijdb.092850mh)

The Australian lungfish (Neoceratodus forsteri) - fish or amphibian pattern of muscle development?

Agata Kacperczyk and Malgorzata Daczewska

Int. J. Dev. Biol. (2008) 52: 279-286

Geometry and mechanics of teleost gastrulation and the formation of primary embryonic axes

Elena M. Cherdantseva and Vladimir G. Cherdantsev

Int. J. Dev. Biol. (2006) 50: 157-168

The germ line lineage in ukigori, Gymnogobius species (Teleostei: Gobiidae) during embryonic development

Taiju Saito, Satoshi Otani, Takafumi Fujimoto, Tohru Suzuki, Takako Nakatsuji, Katsutoshi Arai and Etsuro Yamaha

Int. J. Dev. Biol. (2004) 48: 1079-1085

Germ line development in fishes.

A K Braat, J E Speksnijder and D Zivkovic

Int. J. Dev. Biol. (1999) 43: 745-760

5 yr ISI Impact Factor $(2008)=3.271$

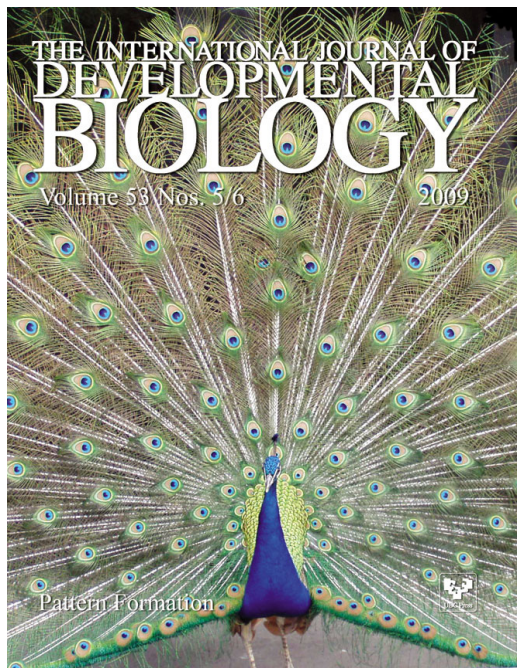

